\title{
TITLE:
}

\section{Laryngeal Regeneration Using Tissue Engineering Techniques in a Canine Model(Abstract_要旨 )}

\section{AUTHOR(S):}

Kitani, Yoshiharu

\section{CITATION:}

Kitani, Yoshiharu. Laryngeal Regeneration Using Tissue Engineering Techniques in a Canine Model. 京都大学, 2011, 博士(医学)

ISSUE DATE:

2011-03-23

URL:

http://hdl.handle.net/2433/142085

RIGHT: 


\begin{tabular}{|l|l|c|c|}
\hline 京都大学 & 博士 (医 学 $)$ & 氏 名 & 木谷 芳晴 \\
\hline 論文題目 & $\begin{array}{l}\text { Laryngeal Regeneration Using Tissue Engineering Techniques } \\
\text { in a Canine Model } \\
\text { (組織工学的手法を用いた犬喉頭再生に関する研究) }\end{array}$ \\
\hline
\end{tabular}

\section{(論文内容の要旨)}

はじめに: 喉頭は、呼吸、摂食、発声などの行為にかかかる重要な器官であるが、腫場、外傷な どにより傷害を受けるとこれらの機能が著しく損なわれる。喉頭が欠損した場合、皮膚、筋肉など 様々な組織で欠損部の再建が行われてきたが、粘膜、筋肉、軟骨など複数の組織からなる喉頭の複 雑な形態を再建寸ることは難しく、いまだ満足のいく結果は得られていない。

一方、近年の再生医療の進歩はめざましく、さまざまな組織や臟器の再生が可能となってきてい る。気管領域では、ポリプロピレンとコラーゲンを材料として作成した人工気管を用いた、気管の 再生が報告されており、実際にヒトに臨床応用されている。しかし、同じ気道である喉頭において は、同じ材料で喉頭の欠損部の再生を試みるも、唾夜の貯留による感染の制御が難しく、また、声 帯が常に動くために、組織が再生寸るのに必要な空間の確保が困難であった。そこで今回、これら の問題を解決するために、感染から材料を保護し、再生の場を維持するために大腿筋膜で材料を被 覆し、犬喉頭部分切除モデルにおいて喉頭の欠損部の再生が可能か検討した。

方法：ビーグル犬を用い、甲状軟骨翼に軟骨から声帯まで達する約 $1.8 \times 1 \mathrm{~cm}$ の欠損を作成した。 濃度の異なる $1 \%$ または $3 \%$ コラーゲン溶液およびポリプロピレンメッシュを用いて複合材料を作成 した。12 頭の犬を $1 \%$ コラーゲンで作成した材料を用いる I 群と $3 \%$ のII群の 2 つに分けた。 I 群 では、材料全体を筋膜で被覆し、吸収糸にて固定した。一方、I群では、材料が内腔側の久筋膜で 被覆されるように材料を固定した。術後の内腔の状態を定期的にファイバーにて観察し、感染やメ ッシュの露出の有無を評価した。II群に関しては、術後6か月の時点で3D-CTによる評価を行い、 また、摘出喉頭を用いて声帯振動の有無を検討した。さらにHE染色により組織の検討を行った。 結果: 内視鏡所見では、良好な再生を認める例があるものの、感染をきたす例、メッシュの露出、 偏位をきたものも認めた。I 群では 6 例中 4 例に局所感染を認めたが、II群では 6 例中 1 例のみで あった。また、I 群では 3 例でメッシュの露出や偏位を認めたが、II群では全例メッシュの露出は 認めなかった。CTでは、声帯の体積が減少し、声帯上面のレベル差が明らかとなった。また、摘 出喉頭を用いた空気力学的検查では、移植側の粘膜波動はかなり制限されており、わずかに声帯振 動を認めるのみであった。組織学的検査では、メッシュが露出したものでは、著明な炎症細胞の浸 潤を認めるものの、露出しなかったものでは、メッシュの周囲に炎症細胞の浸潤は認めず、結合組 織に覆われていた。

考察: 組織が欠損した際に、良好な組織の再生を得るためには、再生の場となる閉鎖した空間が 必要と考え、感染に強い材料である筋膜を使用し閉鎖空間を構築した。I群とII群では、コラーゲ ンの濃度、材料の被覆方法、吸収糸の種類が異なる。欠損部に移植した材料に細胞、血流が入り、 自家組織に取り込まれるまでには時間がかかるが、コラーゲンの濃度を変えることで、移植部位に 死腔が出来るのを防ぎ、筋膜の被覆方法をかえることで、血管が入るまでの時間を短縮しようと試 みた。また、メッシュの固定期間を延ばすため、吸収までの時間の異なる吸収糸を使用した。筋膜 を使用寸ることで、感染が減り、メッシュの露出はなくなったが、C Tや空気力学的検査の結果か らは、声帯のレベル差、体積の減少を認めたため、より正常に近い組織を再生させるためには、新 たに細胞や調節因子を加える必要があると考えられた。
（論文審査の結果の要旨）

喉頭が腫場、外傷により欠損した場合、呼吸、発声などの機能が障害される。従来、様々な組織 で欠損部の再建が行われてきたが、粘膜、筋肉、軟骨など複数の組織からなる喉頭の複杂倠な形態を 再建することは難しかった。近年、気管領域では、組織工学的手法に基づき、ポリプロピレンとコ ラーゲンを材料として作成された人工気管を用いた気管の再生が報告されている。しかし、同じ気 道である喉頭においては、同材料で喉頭の欠損部の再生を試みるも、唾夜の貯留による感染の制御 が難しく、声帯が常に動くために、組織が再生するのに必要な空間の確保が困難であった。そこで 今回、これらの問題を解決するために、同材料に筋膜を加えた新規複合材料を開発し、犬喉頭部分 切除モデルにおいて喉頭の欠損部の再生が可能か検討した。

犬喉頭の甲状軟骨に軟骨から声帯まで達する欠損を作成した。あらかじめ濃度の異なる $1 \%$ また は $3 \%$ コラーゲンとポリプロピレンメッシュを用いて材料を作成し、筋膜で被覆したのち、喉頭の 久損部一固定した。喉頭内視鏡による移植部位の観察およひ組織学的検查を行った。その結果、1\% を使用した群と比べ濃度の高い $3 \%$ コラーゲンを用いた群では、材料への感染が減少し、全例でメ ッシュの偏位や露出は認めなかった。また、組織所見では、メッシュは結合組織に覆われており、 炎症細胞の浸潤も認めず、喉頭枠組みの良好な再生が得られた。

以上の研究は組織工学に基づいた喉頭再生治療の解明に貢献し喉頭切除後の欠損部に対寸る新 たな治療法の開発に寄与寸るところが多い。

したがって、本論文壮尃士 (医学) の学拉論文として価值あるものと認める。

なお、本学位授与申請者は、平成 23 年 3 月 9 日実施の論文内容とそれに関連した試問を受 け、合格と認められたものである。 